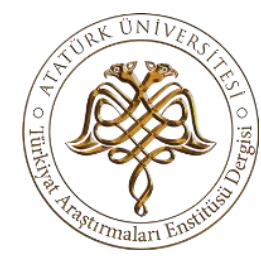

\title{
MUŞ MERKEZDE YER ALAN NADIDE BİR ESER: SELIM PAŞA TAŞ VAKFIYESI
}

A UNIQUE WORK OF ART LOCATED IN MUS CITY CENTRE: SELIM PASHA TAS FOUNDATION CERTIFICATE-CHARTER

\section{KORKMAZ ŞEN}

Dr. Öğr. Üyesi, Fırat Üniversitesi, İnsani ve Sosyal Bilimler Fakültesi, Arkeoloji Bölümü Asst. Prof. Dr., Frat University, Faculty of Humanity and Social Sciences, Department of Archeology ksen@firat.edu.tr (iD) https://orcid.org/0000-0003-4332-7567

\section{Atıf / Citation}

Şen, K. 2020. "Muş Merkezde Yer Alan Nadide Bir Eser: Selim Paşa Taş Vakfiyesi". Türkiyat Araştırmaları Enstitüsü Dergisi - Journal of Turkish Researches Institute. 67, (Ocak-January 2020). 455-470

\section{Makale Bilgisi / Article Information}

Makale Türü-Article Types : Araştırma Makalesi-Research Article

Geliş Tarihi-Received Date : 10.08 .2019

Kabul Tarihi-Accepted Date : 16.10 .2019

Yayn Tarihi- Date Published : 31.01 .2020

doi) : http://dx.doi.org/10.14222/Turkiyat4281

Intihal / Plagiarism
This article was checked by $\mathbb{V}$ iThenticate programında bu makale taranmıştur.

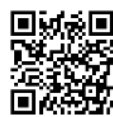

Türkiyat Araştırmaları Enstitüsü Dergisi - Journal of Turkish Researches Institute

TAED-67, Ocak - January2020 Erzurum. ISSN-1300-9052 www.turkiyatjournal.com http://dergipark.gov.tr/ataunitaed 



\title{
Atatürk Üniversitesi • Atatürk University \\ Türkiyat Araştırmaları Enstitüsü Dergisi • Journal of Turkish Researches Institute \\ TAED-67, 2020. 455-470
}

\section{MUŞ MERKEZDE YERALAN NADİDE BİR ESER: SELIM PAŞA TAŞ VAKFIYESI}

\author{
A UNIQUE WORK OF ART LOCATED IN MUS CITY CENTRE: \\ SELIM PASHA TAS FOUNDATION CERTIFICATE-CHARTER
}

KORKMAZ ŞEN

\begin{abstract}
$\ddot{O} \mathbf{z}$
Taş vakfiye, Muş merkezde Kültür Müdürlüğü binasında yer almaktadır. 1.24x0.95 m. ölçülerinde dikdörtgen ölçülerde yapılmış, $4 \mathrm{~cm}$. satır aralığına sahip 23 satırdan oluşan taş bir vakfiyedir. Osmanlı Türkçesiyle yazılmış olan bu vakfiye Muş yerel beylerinden Selim Paşa'ya ait olup 1824 tarihlidir. Vakfiye kurallarına uygun bir şekilde yazıldığı görülmektedir. Yazılar alçak kabartma tekniğiyle taşa işlenmiştir. Buradaki bilgilere göre babası Murat Paşa'nın yaptırmış olduğu cami ve medresesinin bitişiğinde yer alan tekkeye ait bir vakfiyedir. Muş merkeze bağlı Arınç ve Norşin (Sungu) köylerindeki arazilerin tamamı vakfedilmiştir.

$\mathrm{Bu}$ vakıf ile ilintili elde edilen arşiv belgelerinden vakfedilen köylerin Yurtluk/ocaklık statüsünde, yani devlet arazisi olması hasebiyle şer'en ve örfen vakfedilmesi mümkün olmadığı anlaşılmaktadır. Zamanla yöneticiler bu durumu fark etmiş ve bu köylerin vakıf statüsüne son vermişlerdi. Diğer bir husus ise Selim Paşa'nın içinde bulunduğu zor durumdur. Taş vakfiye yazdırıldığı zaman, Selim Paşa'nın merkezî hükümeti ile arası pek de iyi değildi, bu nedenle azledilme ihtimali bulunmaktaydı. $\mathrm{Bu}$ makalede bilimsel bir çalışmaya ilk kez konu olan taş vakfiyenin tanıtılması ve öneminin ortaya konması amaçlanmaktadır.
\end{abstract}

Anahtar Kelimeler: Muş, Selim Paşa, Taş Vakfiye, Tekke ve Muş beyleri

\section{Abstract}

Tas foundation certificate-charter is located in the building of the Directorate of Culture in Mus city centre. It is a stone foundation certificate-charter constructed at measurements of a rectangular with sizes of $1.24 \times 0.95 \mathrm{~m}$ and comprised of 23 lines with spaces of $4 \mathrm{~cm}$. The foundation certificate-charter inscribed in Ottoman Turkish belongs to Selim Pasha, one of Mus governors, and dates from 1824. It is observed that it was inscribed in accordance with the spelling rules of a foundation certificate-charter. The scripts were inscribed onto the stone by means of the bas-relief technique. According to the information obtained, it is a foundation certificate-charter of a tekke situated next to the mosque and madrasah built by his father, Murat Pasha. All Mus-centred lands in Arnc and Norsin (Sungu) villages were consecrated.

It is deduced from the obtained archive documents related to the foundation that as the consecrated villages were with country estate statutes, that is, state lands, it was impossible to consecrate them ecclesiastically and martially. The governors had already discerned this situation in time and terminated the foundation statutes of the villages in question. Another issue is the tough situation of Selim Pasha. When the stone foundation certificate-charter was inscribed, Selim Pasha was not so good with the central government, so it was probable for him to be discharged. This study aims at introducing Tas foundation certificate-charter which is subject to a scientific study for the first time and pointing out its significance in terms of art history.

Key Words: Mus, Selim Pasha, Tas Foundation, Tekke and Mus governors 


\section{Structured Abstract}

Tas Foundation Certificate-Charter is located in the building of the Directorate of Culture in Mus city center. It is a foundation certificate-charter, constructed at measurements of a rectangle with sizes of $1.24 \times 0.95 \mathrm{~m}$. The scripts were inscribed onto the stone by means of the bas-relief technique and divided into 23 lines with horizontal blanking. Line spacings are $4 \mathrm{~cm}$. Some difficulties were encountered in the transcription of the script because of some broken or destroyed parts. Some spelling mistakes are present in the original one. However, it was faithfully transcripted.

The foundation certificate-charter was inscribed in accordance with the spelling rules of a classical foundation certificate-charter. The inscription date and the foundation owner were noted on it. Some verses from the Koran and hadiths, underlining the significance of foundations were included at intervals. It may be inferred from the foundation certificate-charter that the foundation rules were determined through the judicial verbal statement of Selim Pasha, who was the foundation owner, and that the witnesses confirmed that the foundation certificate-charter was coherent with shar'i law.

Furthermore, it is understood that a copy, covering the scripted information on the stone foundation certificate-charter, was delivered by hand and that it would have been supplied when it was considered necessary in any potential events of the conflict. As it was made of stone, the foundation certificate-charter did not include the witnesses' signs and seals. However, it is deduced from the information on it that the signs and seals of the court board and the witnesses were present on the supplied scripted copy. However, no records of the foundation certificate-charter were attained in the document, classified and digitalized during the research in the archive of the General Directorate of Foundations.

It is understood that the foundation was set up after the repairment of an Islamic monastery, which had existed earlier than the foundation certificate-charter. It was noted that the Islamic monastery was built by Selim Pasha's father, Murat Pasha, and located next to Murat Pasha Mosque, affiliated to Murat Pasha Foundation. It may be claimed that this foundation was constructed to serve particularly travelers and poor people passing by the road.

As a local governor, Selim Pasha mentioned in this script heartfeltly that he regarded himself as a considerably insignificant evil-doer in the presence of Allah and that the main purpose of his life was worshipping. He stated that he, indeed, wanted to dedicate his all wealth to Allah's sake, but he did not do such a thing because he knew that it was illicit to deprive the child of inheritance.

It is noteworthy that Selim Pasha preferred the stone style for foundation certificate-charter, which was not so common in Mus and around it. The reason why he resorted to such an option may be explained as follows: One of the factors leading him to take such caution was that he had thought of recording his foundation for a long time. Furthermore, when the political conditions of the period are considered, it is also understood that he also had personal reasons. The problems he had with especially Erzurum governors during his duty term set Selim Pasha a rebellious principal inevitably. The foundation certificate-charter is stated to be dated as 1824. It is understood that in those times, Selim Pasha had problems with Erzurum governors, he was on the point of execution and he took liberties attacking Bitlis, Hinis and Tekman and bringing them under his control before the date of the foundation certificate-charter (around 1820) when it was possible for him to be announced as a traitor. Thus, a few years later than the inscription of the foundation certificate-charter, the central government declared Selim Pasha to be a traitor and discharged him. It is most likely that he must have sensed this situation beforehand and considered inscribing the stone foundation certificate-charter as a sort of self-defense text.

According to a document, found out in the Prime Ministry archive, one-third of incomes in Arinc Village was endowed to Islamic-monastery duty holders and its two-thirds to the science of religion students and needers. However, it was noted that Selim Pasha disregarded shar'i and orfi laws and endowed these lands. It was also stated that all the villages, which were with yurtluk-ocaklik status, 
were invaded in the following years and Arinc Village was ordered not to be endowed as it was also with yurtluk-ocaklik status.

It was clearly stated that similar foundations were also present in Hakkari; however, wrong applications were not true samples. It is understood that it was also renounced to allocate incomes to Islamic monastery and madrassahs as it was not convenient for the law; however, it was decided to transfer some resources from other places to there so that the students could not be badly affected by this situation. Selim Pasha inscribed that the lands, which were given as yurtluk-ocaklik, were submitted to him as properties.

When the content of the foundation certificate-charter is attentively examined, it may be, indeed, evaluated as a self-defense text because it was emphasized in a document that Selim Pasha was an unbeliever and he tortured people and disobeyed the State, whereas it was stated in Tas foundation certificate-charter that he was a quite religious person and his single aim was to be a loyalist to Allah. Moreover, it is revealed that he prayed he prayed somewhere in the document as follows: "Allah forbid me and my people from enemies!". These expressions, in fact, indicate his religious personality and his mercy for his people. It may be inferred from the documents, mentioned above from time to time, that he referred by the word "enemies" to Van administrator Dervis Pasha, Ahlat and Adicevaz Headmaster Sheikh Ahmet and Iranian State. It is also most likely that Selim Pasha had the foundation certificate-charter inscribed onto the stone as he guessed that he was going to be discharged and most probably executed.

In conclusion, the aforementioned foundation certificate-charter in Mus city-center has reached the present day as a unique historical work. Considering its measurements and lining spaces, it may be claimed to be a product of good workmanship. The scripts on it represent a good sample of calligraphy. It is particularly essential to introduce this foundation certificate-charter to the science world for the first time because of the rareness of stone foundation certificate-charters, which reached today.

\section{Giriş}

Vakıf, Arapça kökenli bir kelime olup; alıkoyma, durdurma, tutuklama tamamen vermek ve bağışlamak gibi manalara gelmektedir. Daha geniş anlamıyla bir malın gelecekte ve ebediyete kadar kalıcı bir şekilde hayır işlerinde kullanılmak üzere belli şartlarda ve resmi bir yolla bir kimsenin veya bir topluluğun bırakmış olduğu mal, mülk veya parayı ifade eden hayır müesseselerine denir (Günay 2012:479-486; TDK 1988:1548).

Bir vakfin teşekkülünde üç ana unsur gereklidir. Birincisi vakfeden olmalı, ikincisi vakfedilen mal, mülk veya para, üçüncüsü ise bu durumdan fayda görecek olan kimselerdir (Ertem 1999:111-112). Temel unsur olarak sayılan bu üç hususun hukuki statüsünü belirleyen belgeye ise vakfiye denir.

Vakıfların ortaya çıkışı konusunda farklı görüşler mevcuttur. Ancak tarih boyunca insanoğlu yaşadığı bölgelerde sosyal yardımlaşma ihtiyacını karşılamak için bir şekilde çözümler üretmiş̧ir. Vakıflar, İslam öncesinde kurumsal anlamda mevcut olmamakla birlikte, uygulamada insanların kullanımı için birçok tapınak, çeşme ve kuyu gibi yapıları yapmış olmaları nedeniyle vakıf anlayışının olduğu anlaşılmaktadır (Berki 1965:9).

İslam tarihinde ise ilk vakfiyenin Hz. Ömer tarafından yazdırıldığı rivayet edilmektedir. Hz. Ömer 'in hurmalığını dünya ve ahiret hayatı için faydalı bir işte nasıl kullanabileceğini Hz. Muhammed (s.a.v.) e sorması üzerine, Ömer b. El-Hattab'a kendi şahsi malı olan arazisindeki hurmalığı alınıp satılamayacak ve de miras yoluyla intikal edilemeyecek şekilde dünya ve ahiret hayatı için gelirlerinin fakirlere tahsis edilmesini tavsiye etmiştir (Şeker 1993: 2-3). 
Vakıf mülkiyetinin sağladığı toplumsal fayda anlayışı bakımından Müslüman Türk milletine özgü kurumsallaştı̆ı belirtilebilir (Akgündüz 1986:235). İslamiyet’ten önce de vakıflara önem veren Türk topluluklarının İslamiyet'i kabulüyle birlikte de dini kaynaktan beslenen çok sayıda vakıf müessesesi kurulmuştur. Türkler Anadolu'ya gelmeden önce özellikle eğitim ve sağlık alanlarında vakıflar kurmuştur. Aynı şekilde Anadolu'nun fethedilmesiyle birlikte imar faaliyetleri başlamış ve zengin vakıfların kurulması sağlanmışırı. 13. Yüzyılın sonunda ortaya çıkan Anadolu Beylikleri, kendilerinden önceki Selçuklu devletlerinden almış oldukları vakıf geleneğini sürdürmüşlerdir (Cantay 1994: 147-162; Çetinaslan 2014: 221; Akylldız vd. 2017:149). Bu gelenek vakıf kuruluşlarında daha çok dini hassasiyetin ön planda olduğu Osmanlı Devleti’nde de kurumsal anlamda varlığını sürdürdüğü belirtilebilir.

\section{Taş Vakfiyeler}

Vakfiyeler, taşınır ve taşınmaz belgeler olmak üzere iki kısma ayrılırlar. Taşınır olanlar; kâğıt rulolar, parşömenler, deriler ve ahşap üzerine yazılanlar şeklinde belirtilebilir. Taşınmaz olanlar ise taş üzerine alçak ve yüksek kabartma şeklinde işlenmiş örneklerdir (Şeker 1993: 1; Cantay 1994: 147-162; Tüfekçioğlu 2000: 33-51; Semanur vd. 2017: 53; Yurttaş vd. 2017: 355379). Anadolu Selçukluları döneminden itibaren görülen taşınmaz belge niteliğinde olan taş vakfiyeler, taşınabilir vakfiyelere göre daha çok kalıcı olmanın yanı sıra vakfin devamlılı̆̆ konusundaki kararlıı̆ı̆ın da göstermektedir (Cantay 1994:149).

Taş vakfiyeler bir anlamda kitabe olarak da değerlendirilebilirler. Ancak içerik bakımından kitabe ile taş vakfiyelerde bazı farklılıklar görülmektedir. Kitabelerde genellikle yapının banisi, işlevi, hangi amaçla ve kime inşa ettirildiği, tarihi süreç içerisindeki inşa ve tamirat tarihi ile ilgili bilgiler yer alıken taş vakfiyelerde de bu bilgiler yer almakla birlikte yapıların işlevlerinin ne olduğu ve işlerin kimler tarafindan nasıl yürütüleceği, vakfin gelirleri ve vakfiye şartlarına aykırı hareket edenlere dair beddua gibi ayrıntılı bilgiler yer alır (Tüfekçioğlu 2000: 34).

Aynı zamanda yapıların umuma açık yerlerine yerleştirilen bu belgeler ile ahalinin bilgilendirilmesi sağlanmıştır. Bunun yanı sıra zamanın hükümdar ve yöneticilerinin egemenlik sembolleri olarak da değerlendirilebilirler. Özellikle Selçuklular döneminde kullanılan Es-Sultani şeklinde başlayan kitabeler ve Osmanlı dönemi kitabelerinde yer alan sultanların tuğraları örnek gösterilebilir (Tütüncü 2015: 16).

Anadolu Türk mimarisinde vakfiyelerin yapı üzerinde verilmesi pek yaygın değildir. Kâğıt ve benzeri taşınabilir belge niteliğindeki vakfiyelere göre çok az olmakla birlikte Anadolu'da örneklerine rastlanılmaktadır. Bu minvalde günümüze ulaşan tarihi bilinen belli baş̧ı taş vakfiye örnekleri: Sivas Buruciye Medresesi (1271), Beyşehir Ulu Cami (1297), Erzurum Yakutiye Medresesi (1310), Eskişehir Seyyit Battal Gazi Külliyesi (1369), Bolu Mudurnu Ylldırım Hamamı (1382), Ankara Ahi Yakup Camisi (1392), Tokat Hamza Bey Camisi (1412), Kütahya Yakup Çelebi İmareti (1414 sonrası), Amasya Beyazid Paşa İmareti (1419),Konya Has Bey Dar'ül Huffazı (1421), Karaman İbrahim Bey İmareti (1432), Bursa Umur Bey Camisi (1461), Bursa Mustafa Kemal Paşa Hamza Bey Türbesi (1463), Ahlat Emir Bayındır Camii (1477), Bursa Ebu İshak Camii (1479), İstanbul Bali Paşa Camii (1592), İstanbul-Vefa Defterdar Atıf Efendi Kütüphanesi (1741)ve Hakkari Sitti Bühtan Hatun Mezar Taş1 (1738) taş vakfiyeleri sayılabilir (Tüfekçioğlu 2000: 34-42).

Konumuzu oluşturan taş vakfiye örneği de Osmanlı Devlet'inin Muş'a atamış olduğu yerel beylerden Selim Paşa'ya ait bir taş vakfiyedir. 


\section{Selim Paşa}

Selim Paşa, Muş'lu Alâeddin Bey'in torunu Murat Paşa'nın oğludur (Şen, 2019: 31). Murad Paşa; mirmiran olan babası Maksud Paşa'nın ölümünden sonra (1787) babasının yerine Muş'un yönetimine atanmıştır (BOA, A. DVNS. NŞN. d. 16, 17.Ra.1201 (7 Ocak 1787) s.149). Sadakati ve hizmetleri nedeniyle Osmanlı Devleti nezdinde oldukça itibar görmüştür. 1798 tarihli bir belgede hizmetlerine karşılık Bitlis Hanlarının hasları arasında yer alan Muş’a bağlı bazı yerlerin Haslık statüsü kaldırılarak Murat Paşa'nın yönetimine verilmiş̧ir. Resmi olarak Bitlis hanlarının yönetiminde olan Muş sancağı, bundan böyle Muş beylerinin yönetimine geçmiştir (BOA, A. DVNS. NŞN. d. 16, 22.Ca.1213, (1 Kasım 1798), s.156.). Aynı yılda Muş'un Norşin (Sungu) köyü de Murat Paşa'ya Yurtluk Ocaklık olarak verildiği görülmektedir (BOA, ŞD, 2881/40-4,19.Z.1287 (12 Mart 1871).

Yurtluk/ocaklık, Yavuz döneminde ortaya çıkmış bir uygulamadır. Özellikle İran sınırına yakın bölgelerde Yurtluk/ ocaklık diye adlandırılan, Doğu Anadolu'daki yerel beylerin nüfuzundan faydalanmaya dayanan bir idari sistemdir (Kilıç, 1999: 119; Kodaman, 1986: 13; Gencer, 2011: 76). Beylere hizmet karşlığı olarak verilen toprakların gelirleri babadan oğula miras kalabilir, hatta bu sistemden yararlanan biri, ölüm cezasına çarptrrlsa bile sahip olduğu hakların tamamı oğullarına miras kalırdı. Ancak hiçbir şekilde bu arazileri "vakfedilemez" ve satılamazdı (Kurt, 1992: 27; Gencer, 2011:75-94).

Selim Paşa;1811 Mart'ında azledilen amcası Yusuf Paşa'nın yerine Muş Mutasarrıfllğına atanmıştır (BOA, HAT 520/25422). Selim Paşa görev süresi boyunca birçok sorun ile mücadele etmek zorunda kalmıştı. Özellikle Van yöneticisi Derviş Paşa ile düşmanlık derecesine varan sıkıntılar yaşamıştı (BOA, HAT, 1227/47922, 1228 (1818; Gencer, 2010: 206). Bunun yanında bu dönemde İran'la ciddi skkıntılar yaşanmış, hatta 1821 yılında İran kuvvetleri Osmanlı topraklarına girerek savaş başlatmıştı. (BOA, HAT, 826/37441, 9.S.1236 (16 Kasım 1820; BOA, HAT, 826/37444-A, 25.Ş.1236 (28 Mayıs 1821). Osmanlı yönetimi bu esnada Rum isyanı ile uğraştığı için güçlü bir ordu ile İran kuvvetlerini karşılayamamıştı. İranlılar önlerine çıkan derme çatma Osmanlı birliklerini yenerek Muş'a kadar ulaşmayı başarmışlardı. Selim Paşa İran kuvvetlerinin çok kalabalık olması sebebiyle onlara karşı koyamayacağını düşünmüş, Abbas Mirza'nın yanına gidip kendisine tabi olduğunu söylemiştir. Bu tavrı sebebiyle dönemin Erzurum Valisi Hüsrev Paşa, Selim Paşa'yı ihanet etmekle suçlamıştı.(BOA, HAT 818/37320-F, 8 S.1237 (4 Kasım 1821). Kendisini savunmaya çalş̧an Selim Paşa, İran kuvvetlerine mecburen boyun eğmek zorunda kaldığını, kendisi kadar İranlılardan zarar gören başka kimsenin olmadığımı belirtmişti. Bunun yanında güvenilir kişilere müracaat edilmesi halinde kendisinin sadakatinin anlaşlacağını ifade etmişti. (BOA, HAT, 791/36817-H, 11.Z.1237 (29 Ağustos 1822). Taş vakfiyenin yazdırılış tarihine dikkat edildiği zaman Selim Paşa’nın bu dönemde hem İranlarla hem de Osmanlı yönetimiyle ciddi sorunlar yaşadığı anlaşılmaktadır. (BOA, HAT, 812/37250K, 29 Z. 1241 (1825). Erzurum valiliğine Galip Paşa'nın atanması Selim Paşa için sonun başlangıcı olmuştu. Sebebi tam olarak anlaşılamamışsa da Galip Paşa göreve başlar başlamaz Selim Paşa'yı oldukça zor durumda bırakan uzun bir rapor kaleme almış ve onun bir asi olduğuna dair İstanbul'daki yetkilileri ikna etmeyi başarmıştı. Böylece yaklaşı 15 yıl boyunca Muş mutasarrıflığı görevini yürüten Selim Paşa, Osmanlı yönetiminin talimatıyla azledilmişti. (BOA, HAT, 47949-A; Gencer, 2019: 81-83). 


\section{Selim Paşa Taş Vakfiyesi}

Muş merkezde, Kültür Müdürlüğü binasının içerisinde yer almaktadır. 1.24x0.95 m. ölçülerinde dikdörtgen ölçülerde yapılmış bir taş vakfiyedir. Üzerinde yer alan yazılar alçak kabartma tekniğiyle mermere işlenmiş olup, yatay 22 silme ile 23 satıra ayrılmıştır. Satır aralıkları $4 \mathrm{~cm}$ 'dir. Bazı yerlerinin kırı veya tahrip olması nedeniyle de metnin transkripsiyonunda zorluklar yaşanmıştır. Orijinalinde bazı yazım hataları bulunmaktadır. Ancak tamamen metnin orijinal haline bağlı kalınmıştır.

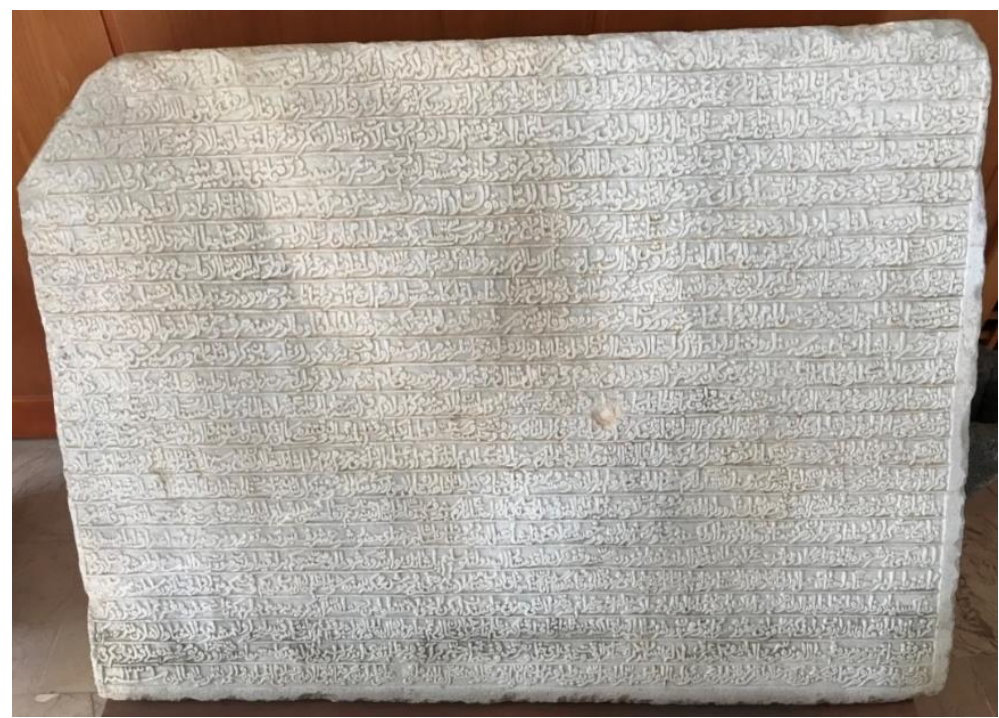

Foto.1: Taş Vakfiye

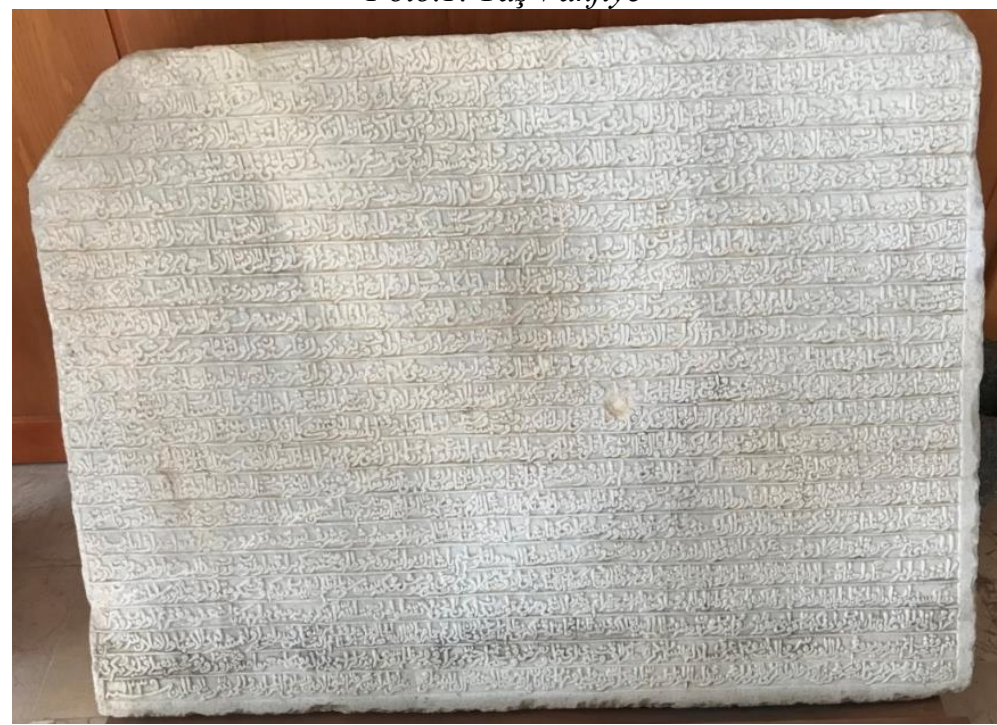

Foto.2: Taş Vakfiye 


\section{Yazılışı}

1-بسم الله الرحمن الرحيم الحمدو الصلاة والسلام علي خير خلقه محمد و آله و صحبه اجمعين أما بعد وقف نامهاء مر عية

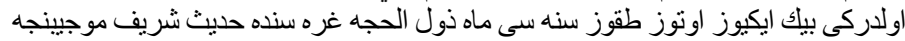

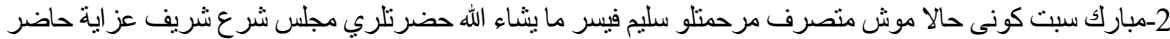

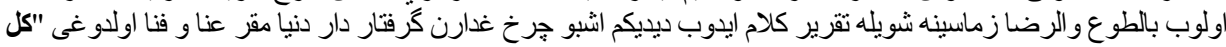

شيء هالك الا وجها له الحكم و اليه

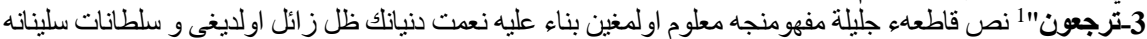

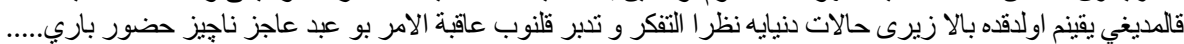

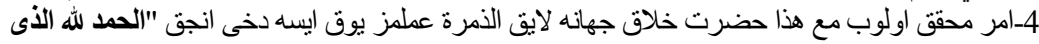

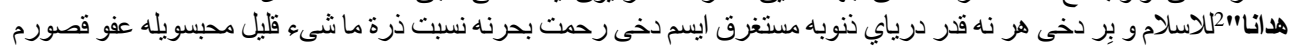

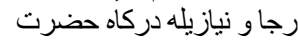

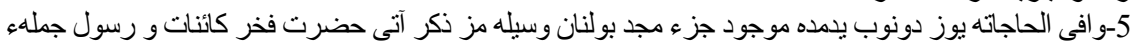

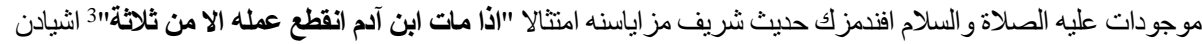

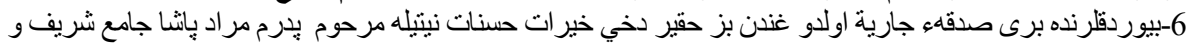

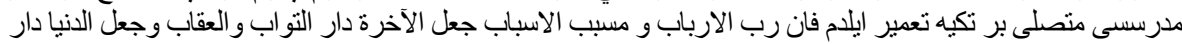

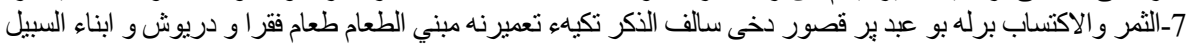

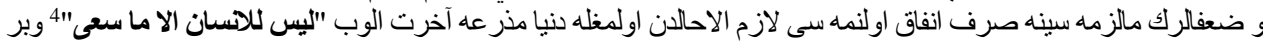

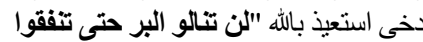

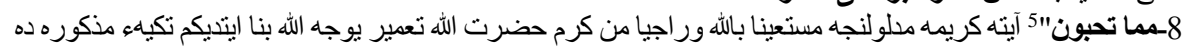

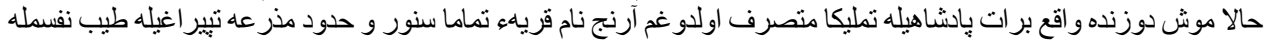

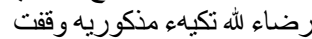

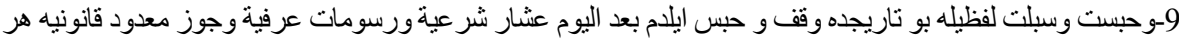

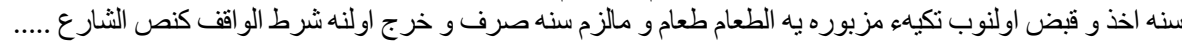

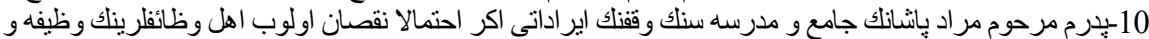

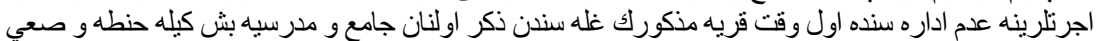

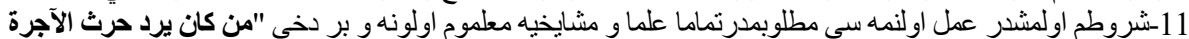

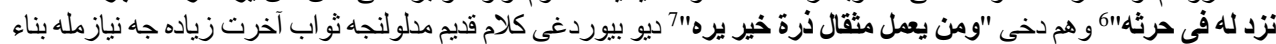

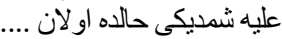

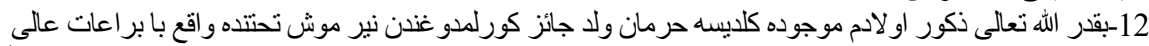

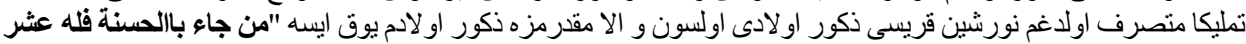

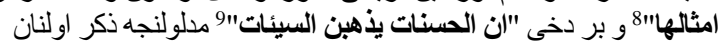

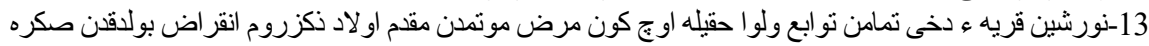

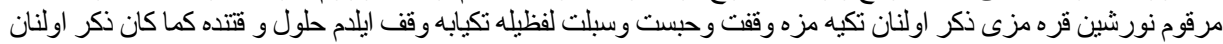

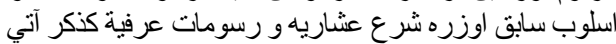

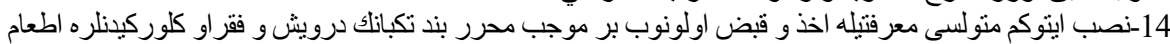

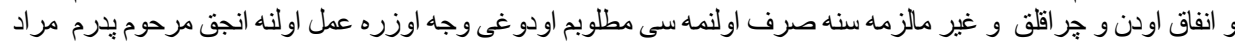

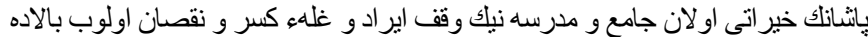

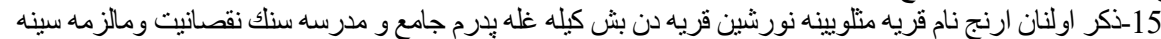

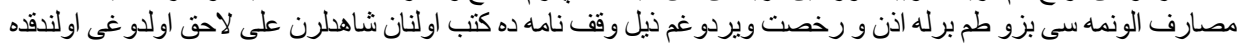
ودخى ذكر اولنان حيرات احسانات و اوقاقاك تماما توليتى ... بالله شيخ عبد القادر حضرن الترينه

${ }^{1}$ el-Kasâs 28/88.

${ }^{2}$ A'râf $7 / 43$.

${ }^{3}$ Müslim, "Vasiyye", 14.

${ }^{4}$ en-Necm 53/39.

${ }^{5}$ Âl-i İmrân 3/92.

${ }^{6}$ eş-Şûrâ 42/20.

7 ez-Zilzâl 99/7.

${ }^{8}$ el-En`âm 6/160.

${ }^{9}$ Hûd 11/114. 


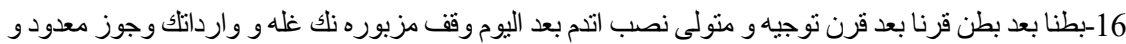

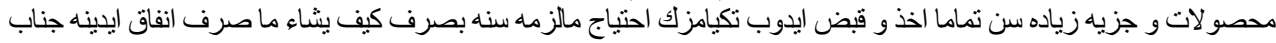

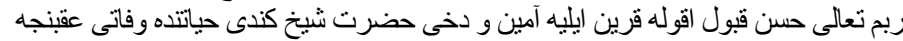

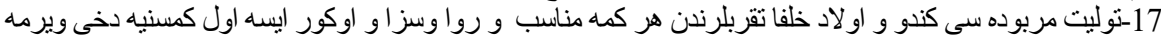

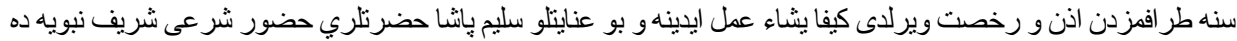

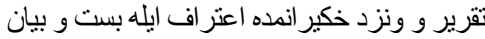

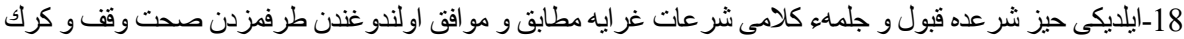

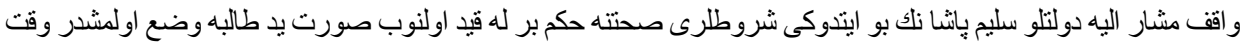
لازمده

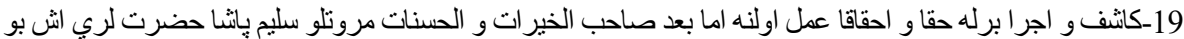

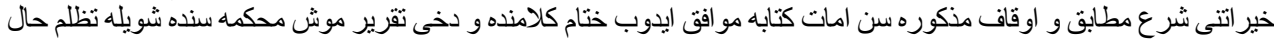

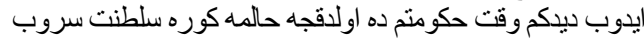

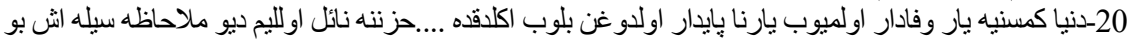

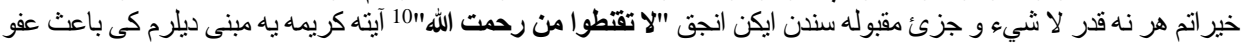

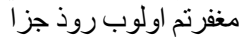

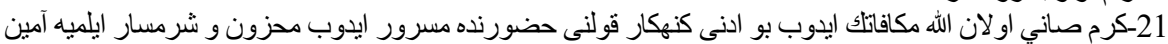

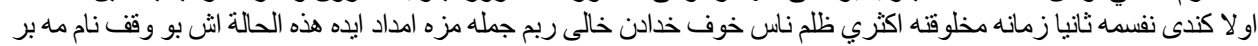

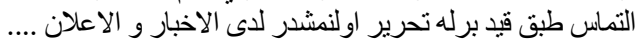

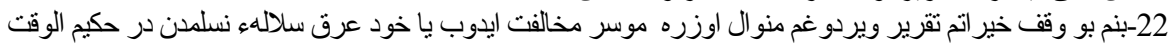

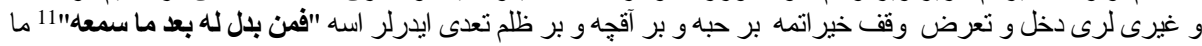

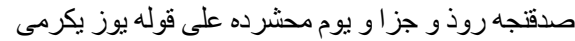

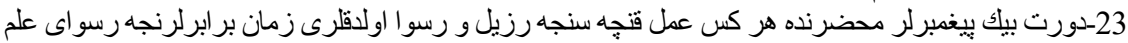

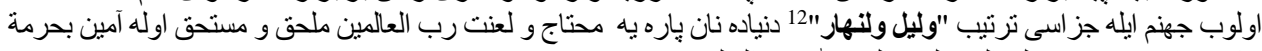

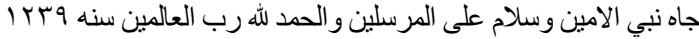

\section{Latin Harfleriyle Okunuşu}

1. Bismi'l-lâhi'r-rahmâni'r-râhîm el-hamdu ve's-salâtuve's-selâmu'alâ hayri halkihi Muhammedin ve âlihi ve sahbihi ecma'în emmâ ba'd vakfnâme-i mer'î oldur ki: Bin iki yüz otuz dokuz senesi mâh-ı Zilhicce gurresinde hadîs-i şerîf mucibince

2. Mübârek sebt günü hâlen Muş mutasarrifi merhametlu Selim feyessir mâ yeşấ' Allâhu hazretleri meclis-i şer'-i şerîf-i 'azâya hâzır olub bi't-tav 'i ve'r-rızâ zemâsina şöyle takrîr-i kelâm idub didi kim işbu çarh-ı gaddârın giriftâr-ı dâr-ı dünya makarr-ı annâ ü fenâ olduğu "külli şey'in hâlikun illâ vechehu lehu'l-hukmu ve ileyhi

3. turce 'ûn" nass-ı kâtı'a celîle mefhûmunca ma 'lûm olmağın binâen 'aleyh ni 'met-i dünyânın zilli zâil olduğu ve saltanat Süleymân'a kalmadı̆̆ yakînim oldukda bâlâ ü zîri âlât-ı dünyâya nazaran tefekkür ve tedebbür kllunub âklbetü'l-emr bu 'abd-ı 'âciz-i nâciz huzûrbârî....

4. emr-i muhakkak olub ma 'ahâzâ hazret-i Hallâk-ı cihâna lâyık'z-zümre amelimiz yok ise dahî ancak "el-Hamdulillâhi'l-lezî hedânâ"li'l-İslâm ve bir dâhi her ne kadar deryâ-yı zunûbe mustağrak isem dâhi rahmet bahrina nisbet zerre-i mâ şey'in kalîl mahbusûyla afv-u kusûrum rica ve niyâzzyla dergâh-ı hazreti

\footnotetext{
${ }^{10}$ ez-Zümer 39/53.

11 el-Bakara 2/181.

${ }^{12}$ Bu ifade Kur'ân-1 Kerim'de pek çok yerde geçer. Başına gelen "vâv" harfiyle ibare "geceye ve gündüze yemin olsun" anlamina gelir.
} 
5. vâfiyyu'l-hâcâta yüz dönüb yedimde mevcûd cüz-i mecde bulunan vesilemiz zikr-i âtî hazret-i fahr-i kâinat ve resul-i cümle mevcudât-l 'aleyhi's-salâtu ve's-sellâm efendimizin hadî̀-i şerî́f mezâyâsina imtisâlen "İzâmâte ibn âdem inkata a 'ameluhu illâ minselâsetin" esyyadan

6. Buyurduklarnnda biri sadaka-i câriyye olduğundan biz hakir dahi hayrât hasenât niyetiyle merhûm pederim Murad Paşa Câmi'-i șerîî ve medresesi muttasil bir tekke ta 'mir eyledim fe inne rabbe 'l-erbabi ve müsebbibi'l esbabi ca 'aleâhiratadaru't-tevvâbbive'l 'ikâbi ve ca 'ale'd-dünyâ dâr

7. es-semeri ve'l iktisâb birle bu abd-i pür-kusûr dâhi sâlifu'z-zikr tekye ta 'mirine mebniyi 't-ta 'âm fukara ve derviş ve ebnâi's-sebîl ve zü afâlartn malzemesine sarf-ı infâk olunması lâzzmü'l-halden olmağla dünya mezra î ahiret olub "Leyse lilinsâni illâ mâse 'a" ve bir dâhi estauzubillâh "Lentenâlu'lbirrehatâtunfikû"

8. "mimmâtuhibbûn" âyet-i kerîme medlulunca musta înen billâh ve râciyen min keremi hazret-i Allah ta 'mir yüce Allah bina ittiğim tekye-i mezkûrede hâlâ Mus düzünde vaki" berât-l padişahiyle temlikken mutasarrif olduğum Arinc nâm karye tamamen sinûr ve hudûd mezra'a toprağıyla tayyib nefsimle rizâenli-l'lâh tekye-i mezkureye vakeftu

9. ve habestu ve sebbiltu lafziyla bu tarihde vakf ve habs eyledim ba 'del yevm 'aşar-l şer'iyye ve rüsûmât-l örfiyye ve cûz-i ma 'dûd-i kânûniye her sene ahz ve kabz olunub tekye-i mezbûreye et-ta 'âmuta 'âm ve malzemesine sarf ve harc oluna şartu' l-vâkf kennâsı 'ş-şâri'

10. Pederim merhum Murad Paşa'nın câmi-î ve medresesinin vakfintn irâdâtı eğer ihtimâlen noksan olub ehli vezâiflerinin vazife ve icraatlarina 'adem-i idaresinde ol vakit karye-i mezkûrun galesinden zikr olunan cami ve medreseye beş kile hinta ve bir sầ

11. şurûtum olmuşdur amel olunması matlubumdur tamamen ulema ve meşâyihaya ma 'l̂̀m oluna ve bir dâhi "Men kâne yurid harse'l-âhire tenezid lehu fi harsihi" ve hem dahi "Fe men ya " mel miskâle zerretin hayren yareh" deyu buyurduğı Kelâm-ı Kadîm medlûlunca sevâb-ı âhiret ziyadece niyazımla binâen 'aleyh şimdiki halde olan....

12.bi-kadri' 'llâhu te 'âlâ zükûr evladım vücuda geldiyse hirmân-ı veled caiz görülmeduğundan neyyir-i Muş tahtinda vâkî bâ berat-l âlì temlîken mutasarrif olduğum Norşin Kariyesi zükûr evladı olsun ve illâ mukadderimizde zükûr evladım yok ise "men câe bi 'l-haseneti felehu 'aşru emsâlihâ" ve bir dahi "İne'l-hasenati yüzhib neseyyiât" medlûlunca zikr olunan

13.Norşin Kariye dâhi tamamen tevâbi 'i ve livâ hakkiyla üç gün maraz-ı mevtimden mukaddem evlad zükûrum inkrâzz bulduktan sonra merkum Norşin karyemizi zikr olunan tekyemize vakkâftu ve habbestu ve sebbiltu lafzzyla tekyaya vakf eyledim hulûl vaktnda kemâ-kân zikr olunan uslûb-i sabik üzere şer î̀ 'aşaraya ve rüsumât-l örfiye zikr-i âtî

14. nasb ettiğüm mütevellisi ma'rifetiyle ahz ve kabz olunub ber mûceb-i muharrer bend-i tekyânin derviş ve fukara ve gelur gidenlere it âm ve infak odun ve çerakllk ve ğayri malzemesine sarf olunması mathûbum olduğu vech üzere amel oluna ancak merhûm pederim Murad Paşa' 'nın hayrâtt olan camiî ve medresenin vakf-l irâd ve galle-i kesr ve noksân olub bâlâda

15. Zikr olunan Arinç nâm kariye misillü yine Norşin kariyeden beş kile galle pederim cami-î ve medresenin noksâniyet ve malzemesine mesârif olunması biz ve tam birle izn ve ruhsat virdügüm zeyl-i vakifnâmede keteb olunan şahidlerin 'âlâ lâhik olundukda ve dahi zikr olunan hayrât-ı ihsânât ve evkâfin tamamen tevelliyeti.... Billâhi șeyh Abdulkadir hazretlerine

16. batna ba'da batin karnen ba'dakarn tevcîh ve mütevelli nasb itdim ba'del yevm vakf-l mezbûrenin galle ve varidâtn ve cüz-i ma'dûd ve mahsulât ve cizye-i ziyâdesin tamamen ahz ve kabz idüb tekyâmızin ihtiyaç malzemesine bi's-sarf keyfe yeșâ emâ sarf-ı infâk idine cenab-ı rabbimte âlâhüsn-ü kabul-ı akvâlakarîn eyleye âmîn ve dahi hazret-i şeyh kendi hayatinda vefatt ukbunca

17.Tevliyet-i merbudesi kendu ve evlad-l hulefâ takarrüblerinden her kime münasib ve reva ve sezâ ve okur ise ol kimesneye dahi virmesine tarafimizdan izn ve ruhsat virildi keyfayeşâe amel idine ve bu inayetlu Selim Paşa hazretleri huzuru şer 'iş̧erîf-i nebeviyyede takrîr ve nezd-i hakirânemde i'tiraf ile best ve beyan 
18. Eylediği hayz-lşar'de kabul ve cümle-i kelamı şeri ât-ı ğarraye mutâbık ve muvaffik olunduğundan tarafimızdan sihhat vakf ve gerek vâkif müş̧arünileyh devletlu Selim Paşa'nın bu ittuği şurûtlart sihhatıne hükm birle kayd olunub suret-i yed tâlebe vaz 'olunmuşdur vakti lazımda

19. Kâşif ve icrâ birle hakkan ve ihkâkan amel oluna amma ba'd sahibu'l-hayrât ve'l-hasanât mürüvvetlu Selim Paşa hazretleri iş bu hayrâtını şer'a mutâbık ve evkâf-ı mezkuresin ümmât-ı kitaba muvaffik idub hitam-ı kelamında ve dahi takrir Muş mahkemesinde şöyle tazallümü hâl idub dediğim vakti hükümetimde oldukça hâlime göre saltanat sürüb

20. Dünya kimesneye yâr-ı vefâdâr olmayub yâr-ı nâpayidâr olduğun bilüb anladıkda....hüznüne nâil olalım deyu mülâhâzastyla iş bu hayrâtım her ne kadar lâ şey'in ve cüz'i makbûlesinden iken ancak "Lâ taknatu min rahmeti'l-lâh" ayeti kerimeye mebnî dilerim ki bâ 'isi afv-u mağfiretim olub rûz-ı cezâ

21.Kerem-i sani' olan Allah mükafâtın idub bu ednâ günahkâr kulunı huzurunda mesrur idub mahzûn ve şer mesâr eylemiye âmîn evvelen kendi nefsime sâniyen zemane mahlûkuna ekseri zulm-ı nâsı havf-ı hüdâdan hâlî rabbim cümlemize imdâd ide hâze'l-hâlet iş bu vakıfnameme ber iltimâs tıbkı kayd birle tahrir olunmuşdur. Lede'l-ihbârve'l-i'lân

22. Benim bu vakfi hayrâtım takrir virduğum minval üzere musir-i muhâlefet idub yahud ırk-ı sülâle-i neslimden der hakimü 'l-vakt ve gayrıları dahl ve taarruz-ı vakf-ı hayrâtıma bir habbe ve bir akçe ve bir zulm te "addi iderler ise "fe men beddelehu ba 'de mâsem 'a" mâ sadıknca rûz-i cezâ ve yevm-i mahşerde 'alâkavlihi yüz yirmi

23. dört bin peygamberler huzurunda herkes amel kançasinca rezil ve rüsva oldukları zaman beraberlerince rüsvayl alem olub cehennem ile cezası tertib ve'leyli ve'n-nehâri dünyada nân pareye muhtaç ve la 'net-i Rabbi'l- 'alemine mülhak ve müstehak ola âmîn bihurmeticah-ı nebiyyu'l-emîn ve selâmun 'ale'lmurselîn ve'l-hamduli'l-lâhirrabbi'l-'âlemîn sene 1239.

\section{Günümüz Türkçesi}

Rahmân ve Rahîm olan Allah'in adıyla. Hamd ve salat yaratılmuslartn en hayırlist olan Hz. Muhammed (s.a.v.), ailesi ve ashabı üzerine olsun... vakifnâme... 1239 (1824) yll Zilhicce (Temmuz) ayı başında hadisi şerifte... Mübarek Cumartesi günü Muş mutasarrfflarından (yönetici) olan merhametli Selim Paşa-Allah dilediğini kolaylaştırı- hazretleri şer î mahkeme heyeti huzurunda, kendi rizasıyla söze şöyle başladı: "Üzerinde yaşadığımız merhametsiz dünyanın geçici olduğu "'O'nun zatından başka her şey yok olacaktır. Hüküm yalnızca O'nundur ve kesinlikle O'na döndürüleceksiniz” âyet-i celilede buyurulduğu gibi herkesçe bilinmektedir. Yani dünya nimetlerinin geçici olduğu, mülkün Hz. Süleymân'a dahi kalmadı̆̆ tarafimdan bilinen bir gerçek iken; dünyanin haline bakp, tefekkür ve tedebbür edildiğinde; işin sonunda bu aciz ve naçiz kulun dahi olmak üzere Yüce Allah 'in huzuruna varllacağ kesin bir emirdir. Bununla birlikte Allah'a layık bir amelimiz yok ise de Müslüman olduğumuz için âyette buyurduğu gibi "Bizi hidayete erdiren Allah'a hamd olsun." Bir de her ne kadar günahlara dalmış isem ve amellerim rahmet denizinde bir zerre miktarı kadar olsa da, hatalarımın affedilmesi rica ve duasıyla; günahları bağıslayan Allah 'in huzuruna dönüp, elimde bulunan yukarıda isimi geçen vakfiyeyi vesile kliyorum. Fahr-ı kâinat ve cümle mevcudâtın peygamberi -selât ve selâm O'nun üzerine olsun- hadisi şerifinde "İnsanoğlu öldüğ̈̈nde üç şey hariç olmak üzere amelleri kesilir" emrinde zikredilen şeylerden biri sadaka-i cariye olduğu düsüncesiyle, rahmetli babam Murat Paşa Câmi'-i şerifi ve medresesine bitişik bir tekke tamir ettim. Sahiplerin sahibi ve sebeplerin yaratıcıs Allah, âhireti tövbe edenlerin ve cezaya duçar olanların; dünyayı da geçim, hayır ve hasenatın yurdu klmuştır. Kusurlarl çok olan bu kul, yukarıda ismi geçen tekke tamiri; fakir, derviş ve yoldan geçenler için yemek ikraminda harcanmak üzere; gerekli olan şeylerin "İnsan için ancak çalıştığı vardır" ve "Sevdiğiniz şeylerden infak etmedikçe iyiliğe asla erişemezsiniz" âyetlerini delil göstererek; Allah 'in yardım ve keremiyle yaptp tamir ettiğim; hala Muş düzlügünde bulunan ve padişahın izniyle mülk edindiğim Arinç köyünü; tüm sinır ve mezralariyla birlikte; kendi isteğimle, Allah rizast için, adı geçen tekkeye 'vakfettim, bağladım, sebil ettim' lafzıyla vakfettim. Öşür vergisi ve kanunda miktar belirlenmiş resmi vergiler çıkartıldıktan sonra; adı geçen tekkenin yemek ve diğer ihtiyaçlarına harcanması; babam merhum Murat Paşa Camiî ve medresesinin kendilerine tahsis edilen vakıf ihtiyaçlarını karşılayamazsa; adı geçen köyün 
gelirinden adı geçen camiî ve medreseye beş kile ve bir sâ' buğday verilmesi vakfin şartı nass (şer 'î kanun) gibidir hükmü gereğince şartımdır. Bunun yerine getirilmesini istiyorum. Bütün ulemâ ve şeyhler bilsinler ki Kur'ân-ı Kerim'de geçen "Kim âhiret kazancinı isterse, onun kazancinı artırırız" ve "Kim zerre ağırlığınca bir hayır işlerse onun mükâfatın görecektir" âyetlerine slğınarak, bu işte kiyamet gününde sevap sahibi olmayl diler, bununla birlikte şuanda mevcut olan ... Allah'in izniyle erkek evladım olursa, evladı terekeden mahrum etmek caiz olmadiğı için Muş'ta padişahın izni ile mülk edindiğim Norşin (Sungu) köyü erkek evlatlartmin olsun. Fakat kaderimizde erkek evlat yoksa, "Kim bir iyilik yaparsa ona on kat vardır" ve "İyilikler kötülükleri giderir" âyetlerinin emrine binaen, Norşin(Sungu) köyünün tamamını livâ hakkayla ölümümden üç gün sonra, erkek evladım olmazsa Norşin(Sungu) köyünü adr geçen tekkemize 'vakfettim, habsettim ve sebil ettim' lafzzyla vakfettim. Vakıf gerçekleștiğinde yukarıda ifade edildiği gibi öşür ve örfü vergiler çıkartıldıktan sonra az önce saydiğım mütevelli heyetince tespit edilip; uygun gördükleri derviş, fakir ve gelip gidenlere; yemek, odun ve aydinlatma malzemelerinin saydığım şartlara göre temini edilmesini istiyorum. Fakat rahmetli babamin hayrati olan Murat Paşa Camiî ve medresesine tahsis edilen vaknfyeterli gelmezse, adr geçen Artnç köyünde olduğu gibi Norşin Köyü'nden beş kile hububatın babamin camiî ve medresesinin ihtiyaçlarına harcanması iznini verdim. Vakıfnâmenin ekinde yazll olan şahitlerin huzurunda ad geçen sadaka ve vakflartn tevelliyyetini (vakfin icaplartnin yerine getirilmesi) Şeyh Abdulkadir hazretlerini, kuşaktan kuşağa aktarılmak üzere mütevelli tayin ettim. Bundan sonra adı geçen vakfin hububat, gelirler, cüz 'i ma'dûd, mahsül ve cizyesinin teslim alınip tekkenin ihtiyaçlarında istedikleri şekilde kullanılsın. Yüce Allah en güzel şekilde kabul etsin. Amin. Birde şeyhin vefatından sonra vakif ile ilgi tasarrufatta bulunmak üzere, akrabalarından hilafet makaminda olanlar arasinda uygun gördükleri kimseye de verilmesine tarafimızdan izin verilmiştir. Istedikleri şekilde tasarrufatta bulunsunlar. Selim paşa, şerî mahkeme huzurunda kendi isteği ile bu kararı verdi. Söylediği tüm sözler şerî hukuka uygun olduğu için, Selim Paşa'nın işaret edilen vakfinın uygun olduğu tarafimızca tasdik edilmişstir. Bu hükümler yazılmış olup, ihtiyaç olduğunda vakfin uygulanmast için bir örneği elden verilmiş̧tir. Hayrat sahibi ve iyiliksever Selim Paşa hazretleri, bu hayratını, hukuka ve kitabin ana esaslarna uygun olarak, Muş mahkemesi huzurunda sözlerini sonlandırtrken şunları da ilave etti: Yönetimim zamanında, kendime göre bir idare şsekli teşkil ettim. Dünyanın kimseye kalmadı̆̆ın ve sonsuz olmadı̆̆ını idrak edip, bu gerçekliğin farkanda olarak, bu hayratım, her ne kadar yok mahiyetinde önemsiz bir şey ise de "Allah' '̇ rahmetinden ümidinizi kesmeyiniz" ayetine muvafik olmasin dilerim. Bu hayratın affedilmeme vesile olmasinı ve mükâfatının kiyamet gününde kerem sahibi Allah tarafindan verilmesini dilerim. Allah bu günahkâr kulunu huzurunda bahtiyar etsin. Mahzun ve mahcup etmesin. Amin. Rabbim, insanlara zulmeden ve Allah'tan korkmayan kimselere karşl bana ve halkıma yardım etsin. İște böyle, iş bu vaklfnâme bire bir kayıt altına alınmıştır. Herkese duyurulur. Benim bu vakf hayratım karar verdigim şeklin dişında, vakuf şartlarina muhalif; neslimden gelenler veya başkalarl, bir tane veya bir akçe dahi hak etmedikleri halde hayratım olan bu vakfa müdahale ederlerse, "Her kim işittikten sonra vasiyeti değiştirirse" ayeti gereğince, hesabin sorulduğu kiyamet gününde, yüz yirmi dört bin peygamber huzurunda, amelini görüp rezil ve rüsva olanlarla birlikte tüm âleme rezil ve rüsva olsunlar. Cehennemde yansinlar. Dünyada ise gece ve gündüz; bir lokma ekmeğe ve bir kuruşa muhtaç olsunlar. Allah'ın lanetine müstahak olsunlar. Âmin. Hz. Peygamber'in hürmetine, peygamberlere selam olsun. Hamd, âlemlerin Rabbi olan Allah'a mahsustur. Sene 1239. 


\section{Değerlendirme ve Sonuç}

Vakfiye klasik vakfiye kurallarına göre yazılmıştır. İlk başta Besmele, Allah'a hamd ve peygambere salavat şeklindedir. Vakfiyenin yazılış tarihi ve vakıf sahibi belirtilmiştir. Vakfin önemini belirten ayet ve hadislere zaman zaman yer verilmiştir. Mahkeme huzurunda vakıf sahibi olan Selim Paşa'nın sözlü beyanı ile vakıf şartlarının belirlendiği, şahitlerinde bu vakfiyenin şer'i hukuka uygun olduğunu tasdik ettikleri görülmektedir. Bunlarla birlikte bu taş vakfiyedeki bilgilerin yazılı olduğu bir kopyasının da elden verildiği, ilerde doğabilecek ihtilaflarda gerekli görüldüğünde temin edebilecekleri anlaşılmaktadır. Taş vakfiye olması nedeniyle şahitlerin imza ve mühürleri yer almamaktadır. Fakat taş vakfiyedeki bilgilerden, elden verilen yazılı suretin üzerinde mahkeme heyeti ile şahitlerin imzalarının olduğu ve mühürlerinin yer aldığ 1 anlaşılmaktadır. Ancak Vakıflar Genel Müdürlüğü arşivinde yaptığımız araştırmada tasnif edilip dijitale aktarılan belgeler içerisinde bahsi geçen vakfiye kaydına ulaşılamamıştır.

Metinde sosyo-kültürel ve siyasal anlamda da bilgiler yer almaktadır. Vakfiyeden anlaşıldığı kadarıyla daha önce var olan bir tekkenin tamir edilmesiyle vakfin kurulduğu anlaşılmaktadır. Tekkenin, babası Murat Paşa tarafından yaptırılmış olan Murat Paşa Cami-i'nin bitişiğinde olduğu ifade edilmektedir. (Foto. 3) ${ }^{13}$. Babasına ait vakfin gelirlerinin yeterli olamayabileceği dile getirilmiş, ihtiyaç hasıl olması durumunda babasının vakfına kendi vakfinın gelirlerinden bir kısmının aktarılabileceği belirtilmiştir. Bu vakfin özellikle yoldan gelip geçen yolculara ve fakirlere hizmet etmek amaciyla meydana getirildiği söylenebilir. Gelirler arasında özellikle buğdayın önemli bir paya sahip olması o dönemde buğday tarımının önemli bir yer teşkil ettiği söylenebilir.

Diğer önemli bir husus ise taş vakfiyede Muş İli'nin padişah tarafindan Selim Paşa'ya yurtluk/ocaklık olarak verildiğinin belirtilmesidir. Ancak daha önce bahsetmiş olduğumuz 1798 tarihli belgede vakfiyeye konu olan Norşin (Sungu) köyünün çok daha önceden babası Murat Paşa'ya yurtluk/ocaklık olarak verildiği anlaşılmaktadır. Osmanlı yönetimi babasına tahsis etmiş olduğu yurtluk-ocaklık arazilerini Selim Paşa 'ya da ihsan etmişti

Yerel bir yönetici olan Selim Paşa bu metinde kendisini Allah'ın huzurunda oldukça küçük ve günahkâr bir kul olarak gördügünü asıl yaşam gayesinin kulluk olduğunu içten bir dil ile ifade etmiştir. Aslında bütün malını Allah yolunda vakfetmek istediğini ancak evladın mirastan mahrum bırakmanın caiz olmaması nedeniyle böyle bir şey yapmadığını belirtmektedir.

Selim Paşa'nın Muş ve çevresinde çok da yaygın olmayan taş vakfiye usulünü tercih etmesi dikkat çekicidir. Neden böyle bir yola tevessül etmiş olduğu sorusuna kanaatimizce şu şekilde yanıt verilebilir. Vakfinı uzun yıllar kayıt altında tutmak istiyor olması, onu böyle bir tedbir almaya sevk eden etmenlerden biridir. Bunun yanında dönemin siyasi ortamı incelendiğinde kendi özelinde de sebeplerin olduğu hemen anlaşılmaktadır. Selim Paşa'nın görev süresi boyunca özellikle Erzurum valileriyle yaşamış olduğu problemler, kaçınılmaz olarak Selim Paşa'yı asi konumuna düşürdüğü bilinmektedir. Vakfiyenin tarihi 1824 olarak belirtilmektedir. Selim Paşa'nın o yıllarda Erzurum valileriyle sorunlar yaşadığı, azledilme durumunun olduğu ve hain ilan edilme ihtimali ortaya çıktığı hatta vakfiye tarihinden önce (1820 dolayları) başına buyruk hareket ettiği Bitlis, Hınıs ve Tekman'a saldırıp kendi idaresi altına aldığı anlaşılmaktadır(Gencer, 2011: 80). Nitekim vakfiyenin yazılmasından birkaç yıl sonra merkezi hükümet onu asi ilan etmiş

\footnotetext{
${ }^{13}$ Not: Yerinde yapılan incelemede Murat Paşa Cami, medresesi ve tekkenin günümüze gelmediği ancak yeniden asıl planına uygun olacak şekilde Vakıflar Bölge Müdürlüğünce arkeolojik kazının yapıldığı görülmüștür. Mevcut sütun vb. kalıntılardan oldukça nitelikli yapılar oldukları anlaşılmaktadır.
} 
ve Selim Paşa'yı azletmişti. Belki de bu durumu daha önce fark etmiş ve bir nevi savunma metni şeklinde taş vakfiyeyi yazmayı uygun görmüş olmalıdır.

Başbakanlık arşivinde bulunan bir belgede ise Arınç Köyü'ndeki gelirlerinin üçte birini tekke görevlilerine, üçte ikisini ise talebe-i uluma ve ihtiyaç sahiplerine vakfetmiş̧ti. Ancak Selim Paşa'nın şer'i ve örfi hukuku göz ardı ederek bu arazileri vakfettiği belirtilmiş daha sonraki yıllarda yurtluk-ocaklık statüsünde olan köylerin tamamına el konulmuştu, Arınç Köyü de yurtluk-ocakllk statüsünde olduğu için vakfedilemeyeceğine hükmedilmişti. Buna benzer vakıflara Hakkâri'de de rastlanıldığına ancak yanlış uygulamaların doğru örnek teşkil etmeyeceği açıkça belirtilmiştir Hukuka uygun olmamaları nedeniyle de gelirlerinin tekke ve medreseye tahsis edilmesinden vazgeçilmişti, ancak talebelerin bu durumdan zarar görmemesi için başka yerlerden buraya kaynak aktarılmasına karar verildiği anlaşılmaktadır(Ek.1) ${ }^{14}$. Selim Paşa, Yurtluk-Ocaklık olarak verilen arazileri temliken (Mülkiyet) kendisine verildiğini yazmıştır.

Vakfiyenin içeriği dikkatle incelendiğinde, aslında bu vakfiyenin bir nevi savunma metni olduğu değerlendirilebilir. Çünkü bir belgede Selim Paşa'nın dinsiz olduğu, halka zulmettiği ve Devlete itaat etmediği vurgulanmıştır (BOA,A. DVNS. NŞN. d. 16, 17.Ca.1242 (17 Aralık 1826). S.154.) Taş vakfiyede ise oldukça dindar biri olduğunu tek gayesinin Allah'a iyi bir kul olmak olduğunu belirtmiştir. Hatta belgenin bir yerinde Allah halkımı ve beni düşmanlarımdan korusun şeklinde de dua ettiği görülmektedir. Bu ifadeler ile aslında dindar olduğunu ve de halkına olan merhametini ifade etmiştir. Düşmanlardan kastı ise Van idarecisi Derviş Paşa, Ahlat ve Adilcevaz Müdürü Şeyh Ahmet ile İran devleti olduğu yukarda zaman zaman bahsettiğimiz belgelerden anlaşılmaktadır. Selim Paşa azledileceğini, belki de öldürülebileceğini tahmin etmiş olmaș nedeniyle de böyle bir vakfiye metnini taşa yazdırmış olabileceği ihtimal dâhilindedir.

Sonuç olarak Muş merkezde bulunan bu vakfiye, nadide bir tarihi eser olarak günümüze ulaşmıştır. Ölçüleri ve satır aralıkları göz önünde bulundurulduğunda iyi bir işçiliğin neticesinde meydana geldiği anlaşılmaktadır. Üzerindeki yazılar, hüsn-i hattın güzel bir örneğini teşkil etmektedir. Günümüze ulaşan taş vakfiyelerin azlığı ve bu vakfiyenin ilk defa bilim dünyasına tanıtılmış olması ayrıca önem arz etmektedir. Bu vakfiye ile birlikte 19. Yüzyılda Muş'ta cereyan eden siyasi olaylar hakkında da yeni bilgiler verilmiştir.

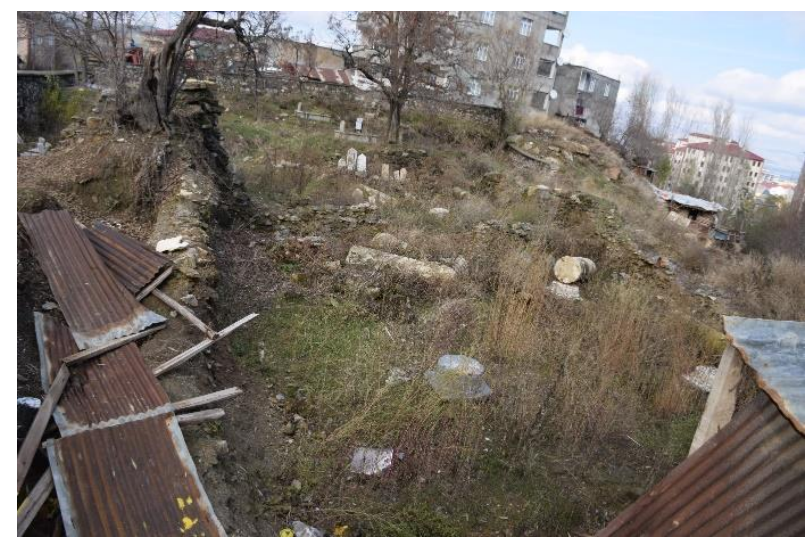

Foto.3:Murat Paşa Camii, Medresesi ve Selim Paşa Tekke Kalıntıları

\footnotetext{
${ }^{14}$ BOA, MVL. 592/7
} 


\section{Kaynaklar}

Arşiv Belgeleri

BOA, A. DVNS. NŞN. d. 16, 17.Ca.1242 (17 Aralık 1826). s.154

BOA, A. DVNS. NŞN. d. 16, 17.Ra.1201 (7 Ocak 1787) s.149

BOA, A. DVNS. NŞN. d. 16, 22.Ca.1213, (1 Kasım 1798), s.156

BOA, HAT 1229/47949-A, 3.Ca.1242 (3 Aralık 1826).

BOA, HAT 520/25422.1225.(1810)

BOA, HAT, 1227/47922, 1228 (1818)

BOA, HAT, 791/36817-H, 11.Z.1237 (29 Ağustos 1822).

BOA, HAT, 812/37250-K, 29 Z. 1241 (1825).

BOA, MVL, 592/7-1, 28.R.1276 (24 Kasim 1859).

BOA, ŞD, 2881/40-4,19.Z.1287 (12 Mart 1871

\section{Kaynak Esreler, Araştırma ve İncelemeler}

Akgündüz, Ahmet. (1986). "Eski ve Yeni Hukukumuzda Devletin Kurduğu Vakıflar". Vakıf Haftasi Dergisi (4), 235-246.

Akyıldız, Yasin ve Ali Rıza Abay. (2017). "Vakıf Müessesesinin Gelişimi Ve Mahiyeti

Tarihsel Bir Değerlendirme”. Yalova Sosyal Bilimler Dergisi, Sayı: 15, 141-157.

Berki, Ali Himmet. (1965). "Vakıfların Tarihi, Mahiyeti, İnkişafi ve Tekâmülü, Cemîyet ve Fertlere Sağladığı Faideler”. Vakıflar Dergisi, 6, 9-13.

Cantay, Gönül. (1994). "Türklerde Vakıf ve Taş Vakfiyeler". Vakıf Haftası Dergisi, 11, 147-162. Çelikbağ Ekinci, Semanur ve Aynur Atmaca Can. (2017). “Osmanlı Şehrinin Araştırılmasında Bir Kaynak: Vakfiye”. Cil.10, Say1. 29/1, Kent Kültürü ve Yönetimi Hakemli Elektronik Dergi, 48-74.

Çetinaslan, Mustafa. (2014). “Taş Vakfiyeler ve Beyşehir Eşrefoğlu Camii'nin Taş Vakfiyesi”.

Uluslararası Orta Anadolu ve Akdeniz Beylikleri Tarihi, Kültürü ve Medeniyeti Sempozyumu-I, 219-251.

Ertem, Adnan. (1999). “Osmanlıdan Günümüze Vakıflar”. Divan Dergisi Bilim ve Sanat Vakfi Yayınları, Sayı: 6. İstanbul, 111-112.

Gencer, Fatih. (2011). "Merkezîleşme Politikaları Sürecinde Yurtluk-Ocaklık Sisteminin Değişimi”. Tarih Araştırmaları Dergisi, Cilt: XXX, Sayı. 49, 75-96.

Gencer, Fatih. (2010). "Van Muhafizı Derviş Paşa İsyanı”, Ankara Üniversitesi Dil ve TarihCoğrafya Fakültesi Tarih Bölümü Tarih Araştırmaları Dergisi, C. 29, S. 47, 197-216.

Gencer, Fatih. (2019). Bitlis ve Muş'un Son Beyleri: Alaaddin Paşazadeler, Libra Yayınları, İstanbul

Günay, Hacı Mehmet. (2012). Vakıf Maddesi, TDV İslam Ansiklopedisi, Cilt. 42, 479-486.

Kılıç, Orhan. (1999). "Yurtluk-Ocaklık ve Hükümet Sancaklar Üzerine Bazı Tespitler". OTAM, Sayı 10, Ankara, 119-137.

Kodaman, Bayram. (1986). Osmanlı Devrinde Doğu Anadolu'nun İdari Durumu. Anadolu Basın Birliği Yayınları, Ankara.

Kur'anı Kerim Meali, Diyanet İşleri Başkanlığı, https://kuran.diyanet.gov.tr/ erişim tarihi: 01.04.2019.

Kurt, Yılmaz. (1992). XVI. Yüzyılda Adana Tarihi. Basılmamış Doktora Tezi, Hacettepe Üniversitesi Sosyal Bilimler Enstitüsü, Ankara. 
Şeker, Mehmet. (1993). "Vakfiyelerin Türk Kültürü Bakımından Özellikleri”. Ege Ün. Edebiyat Fakültesi Tarih İncelemeleri Dergisi, VIII. İzmir, 1-18.

Şen, Korkmaz. (2019). "Belgeler Işığında Hınıs Ulu Camii’nin Tarihlendirilmesi”. Sanat Tarihi Dergisi, 28 (1), 31.

TDK. (1998). Türkçe Sözlük. Cilt:2. 1548. Ankara: Atatürk Dil ve Tarih Yüksek Kurumu.

Tüfekçioğlu, Abdülhamid. (2000). "Medeniyet Tarihimizde Taş Vakfiyeler". Yüzüncü yll Üniversitesi Sosyal Bilimler Dergisi, Van, sayı: 1, 33-51.

Tütüncü, Mehmet. (Mayıs 2015). "Türkiye'de En Eski Türkçe Kitabe Eskişehir Seyitgazi İlçesinde Bulundu (Seyitgazi Kurd Abdal Vakfiyesi-1369 Y1l1)". Düşünce ve Tarih Dergisi, 16-23.

Yurttaş, Hüseyin ve Zerrin Köşklü. (2017). "Erzurum İli Vakfiyelerinde Taş Özetler”. Türk Dünyasl, Dil ve Edebiyat Dergisi, Sayl: 44, 355-379. 
Ek.1:Arınç Köyünün Yurtluk/Ocakllk Statüsünde Olduğuna Dair Belge

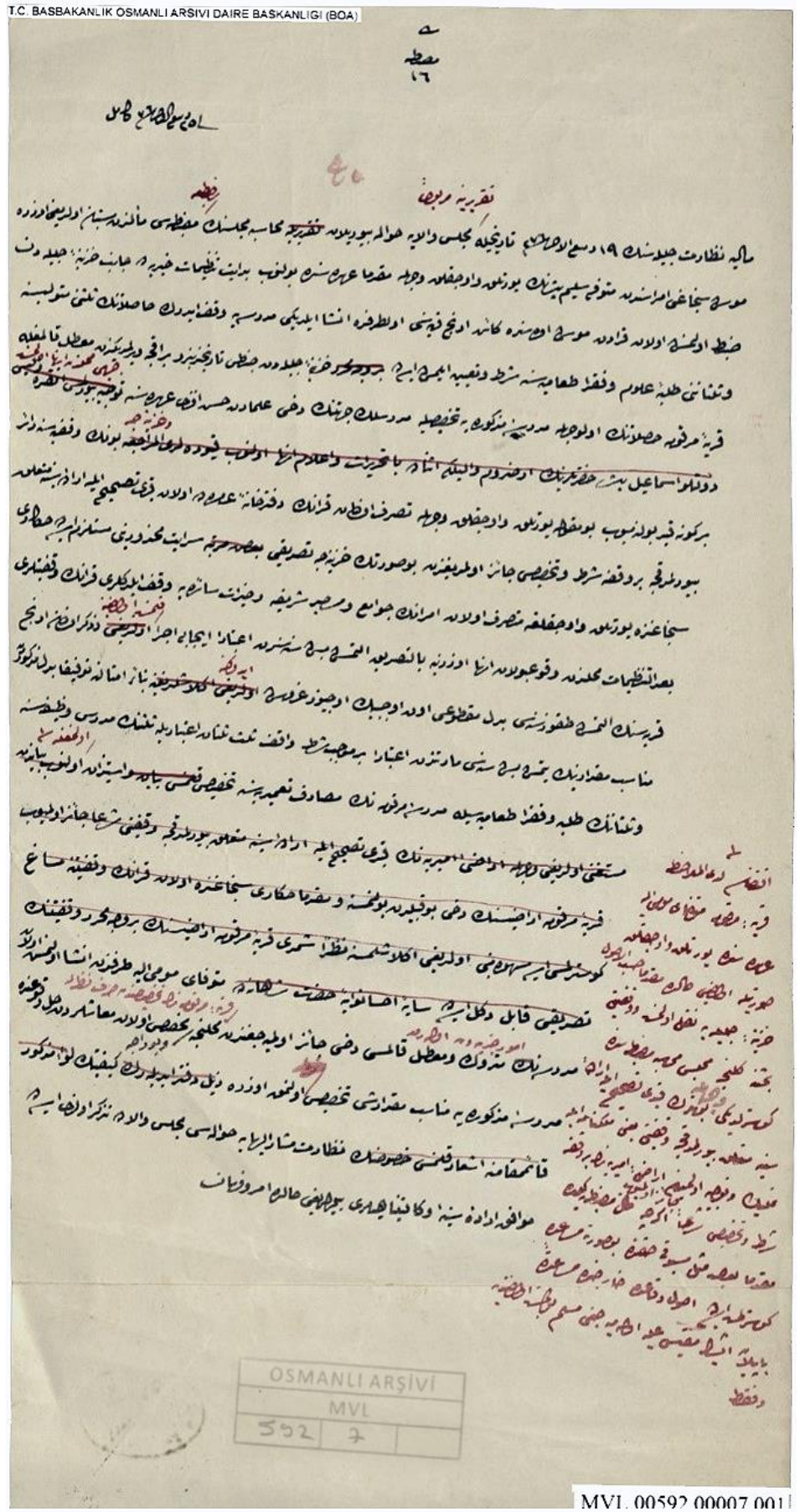

